\title{
The Social Side of Brick and Mortar: the Impact of Brand-Related User- Generated Content on Different Consumer Typologies in Food Retailing
}

\author{
Bettina Beurer-Züllig \\ Zurich University of Applied \\ Sciences \\ bettina.beurer-zuellig@zhaw.ch
}

\author{
Michael Klaas \\ Zurich University of Applied \\ Sciences \\ michael.klaas@zhaw.ch
}

\begin{abstract}
Social media influences most off-line purchasing decisions, thereby impacting the relationship between retailers and (prospective) customers. User-generated content (UGC) is a means of engaging with consumers and shaping their trust perception and loyalty. Based on a sample of 967 food retail customers, we identify four segments into which brand-related UGC consumers can be categorized: Brand Lovers, TrueBlues, Detached Customers, and Confiding Customers. These clusters are distinct in terms of trust toward brand-related UGC, loyalty, brand-related UGC involvement, and demographics. Our findings add to the understanding of digital content marketing consequences by mapping four different brand-related UGC consumer typologies. From a managerial point of view, our findings suggest how to best engage with the determined consumer typologies and highlight the importance of social media for off-line businesses.
\end{abstract}

\section{Introduction}

According to Forrester [1], in 2018, 50\% of off-line retail businesses were impacted by digital interactions, and this figure is expected to grow to $58 \%$ by 2022 . While e-commerce is thriving for most product categories, food retailing is still an off-line business, with only a $2.7 \%$ e-commerce share in Europe [2], accounting for a sales volume of 209.5 billion USD worldwide in 2018 [3]. As the brick-and-mortar and online worlds are fusing, customers are looking for seamless customer experience. Social media is an effective mechanism for engaging with customers [4, $5]$ and has the potential to bridge the online-off-line gap. With $12 \%$ of the marketing budget spent on social media efforts, it has become a main pillar of marketing [6]. Customers no longer just shop for groceries offline, they research product information $[7,8]$, exchange experiences and opinions with peers $[9,10$, $11,12]$, and look for inspiration online [13] before entering a store. Social media and user-generated content (UGC) influence purchasing decisions [14]. According to Watson [15], the average product rating is pivotal for nearly $60 \%$ of all consumers. Social media has positive effects on customer/brand relationships, which in turn positively affect brand trust and brand loyalty $[16,17]$. For the highly competitive food and beverages retail market, brand loyalty is vital for business success. Binding customers closer to a brand and converting them into patrons is a major goal for retailers to ensure sustainable revenue [18]. According to Laroche, Habibi, and Richard [16], brand trust and loyalty are positively affected by increased contacts between customers and elements of brand communities. Hence, social media is used by $63 \%$ of companies to leverage customer loyalty [19].

The link between social media and enhanced customer engagement has been well analyzed in the past, but to our knowledge, there is scarce research on the impact of social media on various customer typologies. In their conceptual framework of digital content marketing (DCM), Hollebeek and Macky [17] recommend a further study of DCM consequences such as trust and loyalty for different consumer segments and firm characteristics. The objective of this study was to examine the impacts of brand-related UGC on the trust, loyalty, and involvement of different typologies of retail customers. This complements the body of research on the effect of social media on brand loyalty by introducing four distinct customer typologies and their responses to brand-related UGC. From a business perspective, the growing influence of digital consumer interaction on purchasing decisions calls for a better understanding of social media's effects on distinct (prospective) customer segments to better plan communication efforts, engage with consumers, and maximize customer loyalty. 


\section{Theoretical Context}

In researching the different effects of social media on customer typologies, understanding customers' involvement and trust in social media, specifically UGC and the loyalty construct, is important.

\subsection{Social Media and UGC}

Unbroken social media popularity is boosting the volume of UGC [20]. Kaplan and Haenlein [5, p. 61] define social media as a group of Internet-based applications that "allows the creation and exchange of user-generated content." According to Laroche et al. [16], UGC is the main characteristic of social media. UGC refers to "any own created material uploaded to the Internet by non-media" $[21$, p. 338] and contains various forms of media content [5]. UGC is not necessarily focused on financial interests [22] and is hence perceived as trustworthy [23]. Brand-related UGC is defined as "the voluntary creation and public distribution of a personal brand meaning" [24, p. 33]. Burmann [25] differentiates between natural-brandrelated UGC, which is unprompted, and stimulated UGC, which is triggered by marketing activities such as voting or contests. Consumers shape brand images by creating brand-related content $[25,26,27,28]$. Consumers rely on UGC for purchasing decisions [21, $29,30]$, as it is perceived to be objective and unbiased $[21,31]$. In comparison with producer-generated content (PGC) that is spread by hired endorsers [21], UGC is perceived to be more credible [21, 29, 31, 32]. UGC consumption has a positive impact on brand awareness, brand loyalty, and perceived quality [16, $17,33,34]$. Content creation positively influences purchase intention [35]. Alalwan et al. [4] give a comprehensive overview on the existing literature on social media in the field of marketing.

\subsection{Trust}

Trust determines customer relationship quality, fosters brand loyalty [36, 37, 38], and can have positive effects on purchasing intentions [39, 40]. Customer loyalty, often referred to as the "Holy Grail" [41, p. 38] of business, is an important key performance indicator for the achievement of a company's economic goals [42]. Past customer experience with a brand is the basis for building trust, resulting in customer loyalty [36, 37]. Companies are exploring ways to employ content in their marketing efforts [43]. PGC often relies on endorsers and celebrities to highlight the advantages of a brand [44] and create trust among consumers [32]. UGC is perceived to be trustworthy, as consumers speak of not only the merits but also the flaws of a brand or a product $[21,32]$. Trust positively impacts purchasing decisions [14, 39]. Following the most frequently applied sociopsychological attitude research approach, trust is determined by cognitive, affective, and conative trust components [45]. Cognitive trust relates to consumers' experiences with a brand and is built on rational thinking and acquired knowledge [39, 46], whereas conative trust reflects the consequences of trust and is composed of the indicators of buying intention, loyalty, and recommendation behavior [39]. Affective trust characterizes a person's emotions toward an object or a person [46], including an affective expectation that the opposite party acts in one's interests [39, 47]. According to Hegner [39], affective trust plays an important role in routine activities and everyday decision-making, which is the case for the majority of grocery purchases. Differences also exist regarding the impact of UGC and PGC on trust components: UGC has a larger effect on cognitive trust than PGC, while PGC has a larger effect on affective trust than UGC [47].

\subsection{Loyalty}

Patronage is a key component of economic success in the retail sector. The positive relationship between trust and loyalty is well documented [37, 38, 39]. Taylor, Celuch, and Goodwin [48] state that trust and brand equity are the most influential antecedents of behavioral and attitudinal brand loyalty. Customer loyalty is composed of the affective, cognitive, conative, and action dimensions $[49,50]$.

UGC is an effective marketing tool with a positive impact on customer loyalty and purchase behavior [51]. Cheong and Morisson [32] point out that electronic word of mouth (eWOM) and UGC are two distinct concepts: eWOM's main characteristic is the dissemination of content, while UGC's main characteristic is creation. Nevertheless, UGC has less influence without eWOM [32]. Customers rely on eWOM and UGC for purchasing decisions [30]. Laroche et al. [16] found that the customer-to-customer relationship enabled by UGC has the largest impact on brand trust and brand loyalty. Conative loyalty relates to recommendation behavior [52]. Although content triggers both cognitive and emotional responses [12, 17], previous research has not distinguished or subdivided customer loyalty in the context of UGC. In our research, we aim to contribute to a multifaceted operationalization of loyalty in a retail setting, as suggested by Too, Souchon, and Thirkell [53]. 


\subsection{Involvement}

Content is key to keeping consumers involved with a brand $[54,55]$. Wang, Yu, and Wei [55] state that peer communication has a large positive effect on product involvement. Involvement influences purchasing decisions, loyalty, and WOM [55]. Because people can easily identify with the protagonists of UGC, it is more involving and persuasive than classical advertising [43]. Involvement determines the depth of information, i.e., UGC processing. Christodoulies, Jevons, and Bonhomme [56] found a closed loop between UGC, involvement, and brand value. Grocery products are generally considered low-involvement products; nevertheless, significant differences in involvement within the category exist [57]. Furthermore, a link between involvement and customer loyalty has been identified [57]. Brand-related UGC consequences comprise emotional and cognitive reactions that ultimately impact behavior [17].

Current literature links UGC to trust, but involvement and positive effects on customer loyalty have also been reported [17]. However, to our knowledge, no evidence or studies exist that explore the impact of brand-related UGC on trust, loyalty, and involvement for diverse customer segments. This study addresses the shortcomings of the existing literature by identifying customer segments regarding their response to brand-related UGC in terms of trust, loyalty, and involvement in a retail environment, as suggested by Hollebeek and Macky [17]. Furthermore, Alalwan et al. [4] suggest that sampling is one of the most important issues, as the vast majority of studies are based on student samples and hence focus on younger age-groups and lack representativeness. We would therefore like to contribute to the current literature by conducting further research presented in this paper with a focus on brand-related UGC and its impact on different customer typologies regarding trust, loyalty, and involvement by performing an analysis with a sample size of 986 food retail customers.

\section{Methods}

We analyzed data from consumers of brand-related UGC of a European grocery chain. To determine the impact of brand-related UGC on the trust and loyalty perception of discriminative consumer typologies, we conducted a cluster analysis. As suggested by Allred [58], clusters of consumers are revealed by performing a cluster analysis.

\subsection{Sample}

The survey was shared through a dark post on Facebook. The post was viewed 155,904 times, and 18,723 persons clicked on the link. The dropout rate was relatively high, with only $5.74 \%$ completing the questionnaire. A total of 1,074 completed questionnaires were examined for anomalies, leading to a sample size of $\mathrm{n}=986$. The sample represents male $(21.2 \%)$ and female $(78.8 \%)$ respondents with a median age of 35-44 years. The gender split of our sample reflects the results of the Hartmann Group [59], as $76 \%$ of the women are the primary grocery shoppers. A total of $50.3 \%$ of the respondents hold a university degree. A total of $42.5 \%$ of the respondents shop more than once a month, while another $25.7 \%$ shop more than once a week at the retailer. A total of $41.5 \%$ of the respondents fulfill at least half of their grocery demands through the retailer. The structured questionnaire featured brand-related UGC and prompted the following subjects: involvement with the featured UGC, trustworthiness of UGC, as well as affective loyalty, and conative loyalty. To rule out medium bias, three different scenarios were shown randomly to the participants: a Facebook post displaying pictures with retailers' groceries and a BBQ scene, an Instagram post showing retailers' product with serving suggestion, or a Google review of the retailer.

\subsection{Measures}

We measured trust by utilizing trust component scales for cognitive and emotional trust from Choi and Lee [47], which have been successfully employed in the context of advertising impact [47,60]. Cognitive trust relates to the appropriateness of UGC regarding product choice, consumers' preferences, and product knowledge (3 items). Emotional trust covers the aspects of security, comfort, and safety when relying on UGC (3 items). Cognitive and emotional trust can be subsumed under trustworthiness [39], which is relevant for the evaluation of UGC. To measure conative and affective loyalty, we employed a twofactorial construct from Jaritz [52]. Conative customer loyalty was captured to determine repurchasing, recommendation, and cross-buying intentions (5 items) [52]. Affective loyalty relates to consumers' commitment and quality of relationship with a brand (3 items) [61]. Involvement with UGC was captured through the Personal Involvement Inventory for Advertising (PIIA) from Zaichkowsky [62]. The 10item scale covers emotional and rational involvement aspects [62]. Scales were adapted to the survey setting by integrating the retailers' brand. Effects were 
measured using statements rated through 7-point Likert scales, with the endpoints "do not agree at all" (=1) and "fully agree" (=7). Demographic data such as age, gender, educational background, domicile, shopping frequency, and fulfillment of grocery needs were also prompted. The questionnaire was pretested with experts, which led to a reformulation of questions for improved fit.

\section{Data Analysis}

This section describes the statistical tests conducted on the data sample. To determine whether brandrelated UGC is perceived differently among (prospective) customers, a cluster analysis was performed. Prior to the cluster analysis, the data were reduced and aggregated through an explorative factor analysis with the objective of bringing to light the interrelation between the single variables.

\subsection{Descriptive Statistics}

Our data show that the majority of participants (56.6\%) agree that the featured UGC is appropriate for evaluating the retailer brand. A total of $39.3 \%$ of the participants feel that the featured content showed good knowledge about the retailer and 37\% agree that the content was able to address their needs and preferences. Our data reveal that consumers trust UGC only to a certain extent, with $32.3 \%$ feeling comfortable, $19.7 \%$ feeling secure, and $23.9 \%$ feeling safe relying on the viewed content. Regarding repurchasing intention, $90.6 \%$ can imagine shopping at the retailer again and $71.6 \%$ agree that they will shop at the retailer in the near future. We received high values for cross-buying intentions: $66.8 \%$ can imagine shopping for those other than their regular products at the retailer. Respondents gave high recommendation rates, with $71.5 \%$ agreeing to recommend the retailer in general and $65 \%$ agreeing to recommend it to friends and family. A total of $33.3 \%$ can identify themselves with the retailer based on the featured UGC. Self-congruity is an important factor for attitudinal acceptance of PGC \& brand-related UGC [63]. Respondents differ about involvement variables, with $52.75 \%$ rating the featured content as important, $47 \%$ as relevant, $47.4 \%$ as appealing, and $35.8 \%$ as needed.

\subsection{Factor Analysis}

Based on the literature review, we employed 24 items to measure the customer engagement of social media consumers in a retail environment. A KaiserMeyer-Olkin (KMO) measure of sampling adequacy was computed to determine whether factor analysis was suitable. We obtained a KMO value of 0.93 for the 24 items, which is considered marvelous [64]. We performed an explorative factor analysis by using the principal component analysis method with Varimax rotation and Kaiser normalization. Factor scores were standardized using the Anderson-Rubin method. According to Hair et al. [65], variables with factor loadings above 0.5 are very significant. After the deletion of four variables owing to low factor loadings, the final factor analysis included 20 variables that load on four factors. The factors explain $70.67 \%$ of the variance. We identified four different constructs that define the customer engagement of social media consumers: Trustworthiness, Conative Loyalty, Affective Loyalty, and Involvement. "Trustworthiness" comprises cognitive components dealing with the suitability of content in terms of preferences, knowledge, and evaluation, as well as emotional components such as security, safety, and comfort regarding the content's reliability. Recommendation behavior and repurchasing intentions are subsumed under "conative loyalty," whereas "affective loyalty" describes the relationship and identification with the branded content. Finally, "involvement" expresses excitement, fascination, and involvement with the content.

\subsection{Construct Validity}

Table 1. Reliability coefficients

\begin{tabular}{lc}
\hline Measure & Alpha \\
\hline Total 20 Items (Customer Engagement) & 0.927 \\
Trustworthiness & 0.929 \\
Conative Loyalty & 0.905 \\
Affective Loyalty & 0.936 \\
Involvement & 0.749 \\
\hline
\end{tabular}

To measure the reliability of the instrument, Cronbach's alpha coefficient was used. Table 1 gives the computed values for the constructs. Eckstein [66] proposes that an alpha of 0.6 or higher is acceptable; therefore, we conclude that the constructs are reliable. 
Table 2. Initial Cluster Centers

\begin{tabular}{lcccc}
\hline & \multicolumn{4}{c}{ Cluster } \\
& $\mathbf{1}$ & $\mathbf{2}$ & $\mathbf{3}$ & \multicolumn{1}{c}{$\mathbf{4}$} \\
\hline Trustworthiness & 0.86219 & -0.75115 & -0.08191 & 0.43381 \\
Conative Loyalty & 0.37451 & 0.64895 & -1.11738 & -0.00248 \\
Affective Loyalty & 0.31536 & -0.23715 & -0.22698 & 0.29526 \\
Involvement & 0.67675 & -0.09488 & 0.28657 & -0.98492 \\
\hline
\end{tabular}

Table 3. Final Cluster Centers

\begin{tabular}{lcrrr}
\hline & \multicolumn{4}{c}{ Cluster } \\
& $\mathbf{1}$ & $\mathbf{2}$ & \multicolumn{1}{c}{$\mathbf{3}$} & \multicolumn{1}{c}{$\mathbf{4}$} \\
\hline Trustworthiness & 0.58574 & -0.89237 & -0.60636 & 0.62160 \\
Conative Loyalty & 0.30147 & 0.81862 & -1.24993 & -0.08443 \\
Affective Loyalty & 0.31436 & -0.47640 & -0.17117 & 0.19120 \\
Involvement & 0.82532 & -0.23604 & 0.03964 & -0.97054 \\
\hline
\end{tabular}

\subsection{Cluster Analysis}

To group participants according to their customer engagement, we subsequently performed a cluster analysis. First, we conducted the single-linkage clustering method to detect participants stating extreme values [67]. We identified 19 outliers, leaving us with 967 participants remaining relevant for cluster formation. In the next step, we utilized the Ward method [68] to determine the number of customer engagement profiles. We arrived at a four-cluster partitioning that ensured the highest increase of the heterogeneity coefficient [66, p. 334]. Table 2 displays the initial cluster centers. As suggested by Punj and Stewart [69], we employed the k-means method [70] with Ward's start partition to achieve a more exact cluster assignment. Table 3 shows the final cluster centers with the mean values of each factor. High values mark consent with the factor, while negative values stand for rejection. Clusters were denominated according to the major components and their interplay. To determine the variance of variables within and across different clusters, a one-way ANOVA was conducted [71]. Variables vary significantly between clusters, as F-value ratios are high between and within clusters and all p-values are $<.001$. Bonferroni posthoc analysis revealed that all factors vary significantly $(p<.005)$ between clusters, with the exception of the factors trustworthiness and affective loyalty between clusters 1 and 4.

\section{Findings}

The final cluster solution consists of four clusters describing customer engagement with the brand-related UGC of retail customers. The first cluster is labeled "Brand Lovers," as participants in this cluster show high values for trustworthiness, conative and affective loyalty, and involvement. With 300 participants, the Brand Lovers are the largest cluster. We termed the second cluster "True-Blues," as the 230 participants belonging to this cluster show the highest values for conative loyalty and hence recommendation behavior. Interestingly, this second cluster shows negative values for all three other factors, indicating that recommendation behavior is not necessarily triggered by social media engagement but rather by actual instore shopping experiences. The smallest cluster comprises 188 participants, and shows negative values for trustworthiness and conative and affective loyalty and values close to zero for involvement; we consequently named this cluster "Detached Customers." Finally, the fourth cluster, termed "Confiding Customers," comprises 249 participants with the highest values for trustworthiness and high values for affective loyalty. "Confiding Customers" believe in the value and trustworthiness of UGC. Table 4 depicts the demographic characteristics of the segments. 
Table 4. Cluster Profiles Based on Demographics

\begin{tabular}{llrrrrr}
\hline & & $\begin{array}{r}\text { Brand } \\
\text { Lover } \\
\mathrm{n}=300\end{array}$ & $\begin{array}{r}\text { True-Blues } \\
\mathrm{n}=230\end{array}$ & $\begin{array}{r}\text { Detached } \\
\text { Customer } \\
\mathrm{n}=188\end{array}$ & $\begin{array}{r}\text { Confiding } \\
\text { Customer } \\
\mathrm{n}=249\end{array}$ & $\begin{array}{r}\text { Total } \\
\mathrm{n}=967\end{array}$ \\
\hline Gender & female & $75.0 \%$ & $82.2 \%$ & $76.1 \%$ & $81.9 \%$ & $78.7 \%$ \\
& male & $25.0 \%$ & $17.8 \%$ & $23.9 \%$ & $18.1 \%$ & $21.3 \%$ \\
Age Groups & $18-24$ & & & & & \\
& $25-34$ & $15.3 \%$ & $18.7 \%$ & $21.3 \%$ & $33.7 \%$ & $22.0 \%$ \\
& $35-44$ & $32.3 \%$ & $22.6 \%$ & $23.9 \%$ & $27.7 \%$ & $27.2 \%$ \\
& $45-59$ & $15.3 \%$ & $17.8 \%$ & $20.2 \%$ & $13.3 \%$ & $16.3 \%$ \\
& 60+ & $22.3 \%$ & $33.9 \%$ & $21.8 \%$ & $19.7 \%$ & $24.3 \%$ \\
Shopping & several times per year & $14.7 \%$ & $7.0 \%$ & $12.8 \%$ & $5.6 \%$ & $10.1 \%$ \\
Frequency & several times per month & $42.7 \%$ & $16.1 \%$ & $50.0 \%$ & $28.9 \%$ & $25.7 \%$ \\
& several times per week & $35.7 \%$ & $35.2 \%$ & $5.9 \%$ & $20.9 \%$ & $26.0 \%$ \\
& daily & $6.0 \%$ & $1.7 \%$ & $1.1 \%$ & $2.8 \%$ & $3.2 \%$ \\
& never & $0.3 \%$ & $0.9 \%$ & $9.0 \%$ & $1.2 \%$ & $2.4 \%$ \\
& & & & & & \\
Fullfillment & 61-100\% & $37.0 \%$ & $36.1 \%$ & $7.4 \%$ & $28.5 \%$ & $28.9 \%$ \\
Grocery & 31-60\% & & & & & \\
Demand & up to 30\% & $30.0 \%$ & $24.8 \%$ & $12.2 \%$ & $17.3 \%$ & $22.0 \%$ \\
\hline
\end{tabular}

\subsection{Brand Lovers}

Brand Lovers show overall high values for trustworthiness, loyalty, and involvement. This segment is characterized by the highest values for affective loyalty and involvement. Brand Lovers identify themselves with the retailer (mean $=4.75$, $\mathrm{SD}=1.38$ ) and feel connected with the brand $($ mean=4.68, $\mathrm{SD}=1.34)$. With a mean value of 5.51 $(\mathrm{SD}=1.15)$, cross-buying intention is the highest among the clusters. Brand Lovers have above-average scores for feeling comfortable (mean=4.67, $\mathrm{SD}=1.09$ ) and secure (mean=4.33, $\mathrm{SD}=1.14$ ), relying on content about the retailer, and judging it as interesting (mean=5.41, SD=1.47) and appealing (mean=5.46, $\mathrm{SD}=1.17)$. Whereas all clusters vary significantly $(p<.001)$ with regard to the fulfillment of grocery demands with the retailer, Brand Lovers and TrueBlues show no significant differences. This segment displays the highest male ratio $(25 \%)$, above average belonging to Gen $\mathrm{Y}$, with $32.3 \%$ falling into the agegroup of 25-34 years. With 300 participants, Brand Lovers constitute the biggest segment.

\subsection{True-Blues}

We termed this cluster True-Blues as participants belonging to this cluster show the highest values for conative loyalty. True-Blues are characterized by high intended repurchasing behavior (mean $=6.63, \mathrm{SD}=0.57$ ) and recommendation intention; $86 \%$ would recommend the retailer and $78.3 \%$ would recommend it to friends and family. True-Blues are frequent shoppers, with $35.2 \%$ shopping several times a week and $36.1 \%$ fulfilling the majority of their grocery demands at the retailer. In contrast to the Brand Lovers cluster, True-Blues are less affectionate toward the brand, displaying low values for involvement and affective loyalty. Consequently, True-Blues rate content as less important (mean=3.37, $\mathrm{SD}=1.61$ ) and relevant (mean=3.16, $\mathrm{SD}=1.72$ ). A total of $33.9 \%$ of the participants of this segment are Baby Boomers, who belong to the age-group of 45-59 years. A total of $82.8 \%$ of the cluster are female.

\subsection{Detached Customers}

With 188 participants, detached customers are the smallest cluster. Detached customers display weak 
links with the retailer; $9 \%$ never and $50 \%$ only shop several times a year in one of the retailer's shops. A total of $80.3 \%$ cover less than a third of their grocery demands at the retailer. Accordingly, this segment is characterized by negative values for trustworthiness and conative and affective loyalty and low values for involvement. Detached customers do not think that the featured content meets their needs or preferences (mean=2.55, $\mathrm{SD}=1.38$ ), nor do they believe that they are secure $($ mean $=2.31, \mathrm{SD}=1.25)$ or safe $($ mean $=2.39$, $\mathrm{SD}=1.25$ ) relying on it. A total of $82.9 \%$ rate the featured content as unimportant, and $67.1 \%$ state that it is not needed. Being $23.9 \%$ female, the cluster is above-average male.

\subsection{Confiding Customers}

This second-largest segment $(n=249)$ has the highest value for trustworthiness and appreciates UGC as an important source for information about a brand. Confiding customers feel that the featured content is appropriate for evaluating the retailer (mean=4.92, $\mathrm{SD}=1.05)$, showing good knowledge about it (mean=4.27, $\mathrm{SD}=1.27$ ). For this segment, UGC plays an important role for trust formation and purchasing decisions. A total of $57 \%$ agree that the featured content is important, and $47 \%$ believe it to be valuable. Confiding customers are the youngest segment, with $33.7 \%$ belonging to Gen $\mathrm{Z}$ : $18-24$ years old. Confiding customers significantly differ $(p<.005)$ from the other clusters in terms of age. Our results are in line with that of Taylor, Lewin, and Strutton [63], who found that younger people aged 19-24 have more positive attitudes toward social media. This segment is aboveaverage female, at $81.9 \%$.

\section{Implications}

Our study shows the existence of UGC consumer typologies that are distinctively different in their responses to brand-related UGC regarding trustworthiness perception, loyalty, and involvement, as well as demographics. Our research adds to the literature on DCM by identifying consumers' typologies of brand-related UGC and their responses in terms of trustworthiness, loyalty, and involvement, as requested by Hollebeek and Macky [17]. As mentioned by Alalwan et al. [4], the majority of social media studies are based on student samples; therefore, our research gives insight into diverse age-groups by employing a sample of brand-related UGC consumers of a European food and beverages retailer. Furthermore, we add to the understanding of the impact of social media, specifically brand-related UGC for brick-and-mortar stores, indicating that brandrelated UGC is especially involving for Gen $Z$ customers.

According to Burmann [25, p. 3], "UGC is a very effective branding tool." While we have shown that brand-related UGC is engaging for two clusters, namely, Brand Lovers and Confiding Customers, marketing to Detached Customers and True-Blues requires different routes. Brand Lovers, above average belonging to Gen Y, show a strong identification and trustworthiness perception with the retailer brand; this is in line with the study of Balakrishnan et al. [72], who put forth that social media marketing is effective in promoting trust and purchase intention for Gen $\mathrm{Y}$ customers. From a marketer's perspective, Brand Lovers are predestined brand evangelists, as identification with a brand is a strong motivator for the creation of brand-related UGC [13]. True-Blues show high conative loyalty based on past shopping experiences and high recommendation behavior. This segment shows low affective loyalty and skepticism regarding the credibility of brand-related UGC. The impact of PGC on this segment is worth considering, as the displayed recommendation behavior is a fruitful basis for positive eWOM. Detached Customers only display weak links with the retailer, as food and beverages retail is highly competitive; actions such as vouchers, special offers, or events to turn this segment into loyal shoppers are worth examining in further research. Confiding Customers above average belong to Gen Z. Like Brand Lovers, they show high values for trustworthiness and positive values for affective loyalty. According to Bayindir and Winther Paisley [73], 24\% of Gen Zers discover brands through social media recommendations. This is strengthened by our results of high credibility values for brand-related UGC in this cluster. Our study highlights the importance of social media for brick-and-mortar businesses and gives first indications of how managers could target the mapped typologies.

\section{Limitations}

This study is based on single-case data; therefore, further research is needed to verify and check the generalizability of the results found in this research. In addition, recruitment of participants through Facebook poses a limitation in terms of generalizability. The design of the UGC could possibly affect trustworthiness and loyalty perception as well as involvement. Future research should take into account the influence of content design, media type, and source criteria. Furthermore, a longitudinal study regarding 
clusters, as mentioned and proposed by Laroche et al. [34], would contribute further to the existing literature and could possibly identify interesting changes in the perception and effects of UGC over time.

\section{References}

[1] Forrester, "Digitally impacted retail sales in 2018: Still only half of retail. Highlights from the Forrester data: digitalinfluenced retail sales forecast, 2017 to 2022 (US)," March 26, 2018 [Online]. Available: https://www.forrester.com/report/Digitally+Impacted+Retail + Sales+In+2018+Still+Only+Half+Of+Retail/-/ERES122907

[2] Statista, "Vertriebskanäle im Markt für Lebensmittel," Statista, July 2018.

[3] Statista, "eCommerce report 2019," in Statista Digital Market Outlook-Market Report. Hamburg, Germany, 2018 [Online]. https://www.statista.com/outlook/digital-markets

[4] A. A. Alalwan, N. P. Rana, Y. K. Dwivedi, and R. Algharabat, "Social media in marketing: A review and analysis of the existing literature," Telematics and Informatics, vol. 2017, no. 34, pp. 1177-1190, 2017.

[5] A. M. Kaplan and M. Haenlein, "Users of the world, unite! The challenges and opportunities of social media," Business Horizons, no. 53, pp. 59-68, 2010.

[6] T. C. Survey, "The CMO Survey: Highlights and Insights Report," American Marketing Association, 2018 [Online]. Available: cmosurvey.org

[7] M. Hamilton, V. D. Kaltcheva, and A. J. Rohm, "Social media and value creation: The role of interaction satisfaction and interaction immersion," Journal of Interactive Marketing, vol. 36, pp. 121-133, 2016.

[8] Z. Zhu, J. Wang, X. Wang, and X. Wan, "Exploring factors of user's peer-influence behavior in social media on purchase intention: Evidence from QQ," Computers in Human Behavior, vol. 63, pp. 980-987, 2016.

[9] C. M. K. Cheung, M. K. O. Chan, and N. Rabjohn, "The impact of electronic word-of-mouth," Internet Research, vol. 18 , no. 3, 2008.

[10] I. Erkan and C. Evans, "The influence of eWOM in social media on consumers' purchase intentions: An extended approach to information adoption," Computers in Human Behavior, vol. 61, pp. 47-55, 2016.

[11] S. C. Chu and Y. Kim, "Determinants of consumer engagement in electronic word-of-mouth (eWOM) in social networking sites," International Journal of Advertising, vol. 30, no. 1, pp. 47-75, 2011.

[12] A. J. Kim and K. K. P. Johnson, "Power of consumers using social media: Examining the influences of brandrelated user-generated content on Facebook," Computers in Human Behavior, vol. 58, pp. 98-108, 2016.

[13] S. V. Halliday, "User-generated content about brands: Understanding its creators and consumers," Journal of Business Research, vol. 69, pp. 137-144, 2016.

[14] E. W. K. See-To and K. K. W. Ho, "Value co-creation and purchase intention in social network sites: The role of electronic word-of-mouth and trust: A theoretical analysis," Computers in Human Behavior, vol. 31, pp. 182-189, 2014.
[15] J. Watson, A. P. Ghosh, and M. Trusov, "Swayed by the numbers: The consequences of displaying product review attributes," Journal of Marketing, vol. 82, no. 6, pp. 109131,2018

[16] M. Laroche, M. R. Habibi, and M.-O. Richard, "To be or not to be in social media: How brand loyalty is affected by social media?" International Journal of Information Management, vol. 33, pp. 76- 82, 2013.

[17] L. D. Hollebeek and K. Macky, "Digital content marketing's role in fostering consumer engagement, trust, and value: Framework, fundamental propositions, and implications," Journal of Interactive Marketing, vol. 45, pp. 27-41, 2019

[18] J. Hogreve, A. Iseke, K. Derfuss, and T. Eller, "The service-profit chain: A meta-analytic test of a comprehensive theoretical framework," Journal of Marketing, vol. 81, no. 3, pp. 41-61, 2017.

[19] S. M. Examiner, "Welcher Nutzen ergibt sich durch den Einsatz von Social Media Marketing für Ihr Unternehmen," 2018.

[20] X. Wang and Y. Li, "Trust, psychological need, and motivation to produce user-generated content: A selfdetermination perspective," Journal of Electronic Commerce Research, vol. 15, no. 3, pp. 241-253, 2014.

[21] A. Z. Bahtar and M. Muda, "The impact of usergenerated content (UGC) on product reviews towards online purchasing: A conceptual framework," Procedia Economics and Finance, vol. 37, pp. 337-342, 2016.

[22] R. Stöckl, P. Rohrmeier, and T. Hess, "Why customers produce user generated content," in Web 2.0: Neue Perspektiven für Marketing und Medien. Berlin, Heidelberg: Springer, 2008, pp. 271-287.

[23] I. A. Mir and K. U. Rehman, "Factors affecting consumer attitudes and intentions toward user-generated product content on YouTube," Management \& Marketing Challenges for the Knowledge Society, vol. 8, no. 4, pp. 637654, 2013.

[24] U. Arnhold, User-Generated Branding. Wiesbaden: Gabler, 2010.

[25] C. Burmann, "A call for 'user-generated branding," Journal of Brand Management, vol. 18, pp. 1-4, 2010.

[26] D. Rowles, Digital Branding: A Complete Step-by-Step Guide to Strategy, Tactics and Measurement. Philadelphia: Kogan Page, 2014.

[27] Y. A. Kim and J. Srivastava, "Impact of social influence in e-commerce decision making," in ICEC07. Minneapolis, MN, US, 2007: ACM, pp. 293-301.

[28] K.-Y. Goh, C.-S. Heng, and Z. Lin, "Social media brand community and consumer behavior: Quantifying the relative impact of user- and marketer-generated content," Information Systems Research, vol. 24, no. 1, pp. 88-107, 2013.

[29] K. MacKinnon, "User generated content vs. advertising: Do consumers trust the word of others over advertisers?" The

Elon Journal of Undergraduate Research in Communications, vol. 3, no. 1, pp. 14-22, 2012.

[30] U. Ramanathan, N. Subramanian, and G. Parrott, "Role of social media in retail network operations and marketing to enhance customer satisfaction," International Journal of Operations \& Production Management, vol. 37, no. 1, pp. 105-123, 2017. 
[31] M. I. Anwar and K. U. Rehman, "Factors affecting consumer attitudes and intentions toward user-generated product content on YouTube," Management \& Marketing, vol. 8 , no. $4,2013$.

[32] H. J. Cheong and M. A. Morrison, "Consumers' reliance on product information and recommendations found in UGC," Journal of Interactive Advertising, vol. 8, no. 2, pp. 38-49, 2008.

[33] B. Schivinski and D. Dabrowski, "The impact of brand communication on brand equity through Facebook," Journal of Research in Interactive Marketing, vol. 9, no. 1, pp. 3153, 2015.

[34] M. Laroche, M. R. Habibi, M.-O. Richard, and R. Sankaranarayanan, "The effects of social media based brand communities on brand community markers, value creation practices, brand trust and brand loyalty," Computers in Human Behavior, vol. 28, pp. 1755-1767, 2012.

[35] E. C. Malthouse, B. J. Calder, S. J. Kim, and M. Vandenbosch, "Evidence that user-generated content that produces engagement increases purchase behaviours," Journal of Marketing Management, vol. 32, no. 5-6, pp. 427-444, 2016.

[36] E. Delgado-Ballester and J. L. Munuera-Alemán, "Does brand trust matter to brand equity?" Journal of Product \& Brand Management, vol. 14, no. 3, pp. 187-196, 2005.

[37] D. Ball, P. S. Coelho, and A. Machás, "The role of communication and trust in explaining customer loyalty: An extension to the ECSI model," European Journal of Marketing, vol. 38, no. 9/10, pp. 1272-1293, 2004.

[38] A. Chaudhuri and M. B. Holbrook, "The chain of effects from brand trust and brand affect to brand performance: The role of brand loyalty," Journal of Marketing, vol. 65, no. April, pp. 81-93, 2001.

[39] S. Hegner, Die Relevanz des Vertrauens für das identitätsbasierte Management globaler Marken (Dissertation). Bremen: Universität Bremen, 2012.

[40] H. D. McKnight, V. Choudhury, and C. Kacmar, "The impact of initial consumer trust on intentions to transact with a web site: A trust building model," The Journal of Strategic Information Systems, vol. 11, no. 3, pp. 297-323, 2002.

[41] S. J. H. McAlexander, W. J. Schouten, and H. F. Koening, "Building brand community," Journal of Marketing, vol. 66, no. 1, pp. 38-54, 2002.

[42] H. Diller, "Kundenbindung als Marketingziel," Marketing ZFP, vol. 18, no. 2, pp. 81-94, 1996.

[43] D. V. Thompson and P. Malaviya, "Consumer-generated ads: Does awareness of advertising co-creation help or hurt persuasion?" Journal of Marketing, vol. 77, no. 3, pp. 33-47, 2013.

[44] Y. Verhellen, N. Dens, and P. D. Pelsmacker, "Consumer responses to brands placed in YouTube movies: The effect of prominence and endorser expertise," Journal of Electronic Commerce Research, vol. 14, no. 4, 2013.

[45] C. Frings, Soziales Vertrauen. Wiesbaden: VS Verlag für Sozialwissenschaften, 2010.

[46] J. Vollmar, R. Becker, and I. Hoffend, Macht des Vertrauens. Wiesbaden: Springer Gabler, 2013.

[47] B. Choi and I. Lee, "Trust in open versus closed social media: The relative influence of user- and marketergenerated content in social network services on customer trust," Telematics and Informatics, vol. 34, no. 5, pp. 550$559,2017$.

[48] S. A. Taylor, K. Celuch, and S. Goodwin, "The importance of brand equity to customer loyalty," Journal of Product \& Brand Management, vol. 13, no. 4, pp. 217-227, 2004.

[49] R. L. Oliver, Satisfaction: A Behavioral Perspective on the Consumer: A Behavioral Perspective on the Consumer, 2nd ed. New York: Routledge, 2014.

[50] M. Gommans, K. S. Krishman, and K. B. Scheffold, "From brand loyalty to e-loyalty: A conceptual framework," Journal of Economic \& Social Research, vol. 3, no. 1, 2001.

[51] S. Crofton and R. Parker, "Economic impacts of introducing social media as marketing tools in Atlantic Canadian tourism websites," in Economic Business and Historical Society Annual Conference. Las Vegas, Nevada, 2012.

[52] S. Jaritz, Kundenbindung und Involvement: eine empirische Analyse unter besonderer Berücksichtigung von Low Involvement. Wiesbaden: Gabler, 2008.

[53] L. H. Y. Too, A. L. Souchon, and P. C. Thirkell, "Relationship marketing and customer loyalty in a retail setting: A dyadic exploration," Journal of Marketing Management, vol. 17, no. 3-4, pp. 287-319, 2001.

[54] H. G. Pereira, M. d. F. Salgueiro, and I. Mateus, "Say yes to Facebook and get your customers involved! Relationships in a world of social networks," Business Horizons, vol. 57, p. 695-702, 2014.

[55] X. Wang, C. Yu, and Y. Wei, "Social media peer communication and impacts on purchase intentions: A consumer socialization framework," Journal of Interactive Marketing, vol. 26, pp. 198-208, 2012.

[56] G. Christodoulides, C. Jevons, and J. Bonhomme, "Memo to marketers: Quantitative evidence for change: How user-generated content really affects brands," Journal of Advertising Research, vol. 52, no. 1, pp. 53-64, 2012.

[57] S. Knox and D. Walker, "Empirical developments in the measurement of involvement, brand loyalty and their relationship in grocery markets," Journal of Strategic Marketing, vol. 11, no. 4, pp. 271-86, 2003.

[58] C. R. Allred, S. M. Smith, and W. R. Swinyard, "E-shopping lovers and fearful conservatives: A market segmentation analysis," International Journal of Retail \& Distribution Management, vol. 34, no. 4/5, pp. 308-333, 2006.

[59] H. Group, "Food shopping in America 2017," 2018 [Online]. Available: $\underline{\mathrm{http}: / / \text { store.hartman- }}$ group.com/content/Food $\% 20$ Shopping $\% 20$ in $\% 20$ America $\%$ 202017\%20Report\%20Overview.pdf

[60] S. X. Komiak and I. Benbasat, "Understanding customer trust in agent-mediated electronic commerce, web-mediated electronic commerce, and traditional commerce," Information Technology and Management, vol. 5, no. 1/2, pp. 181-207, 2004.

[61] T. Hennig-Thurau and U. Hansen, "Some reflections on the state-of-the-art of the relational concept," in Relationship Marketing Gaining Competitive Advantage through Customer Satisfaction and Customer Retention, T. HennigThurau and U. Hansen, Eds. Berlin, Heidelberg: Springer, 2000, pp. 3-27. 
[62] J. L. Zaichkowsky, "The personal involvement inventory: Reduction, revision, and application to advertising," Journal of Advertising, vol. 23, no. 4, pp. 5970, 1994.

[63] D. G. Taylor, J. E. Lewin, and D. Strutton, "Friends, fans, and followers: Do ads work on social networks? How gender and age shape receptivity," J. Adv. Res., vol. 51, no. 1, pp. 258-276, 2011.

[64] G. Hutcheson and N. Sofroniou, The Multivariate Social Scientist. London: Sage, 1999.

[65] J. F. Hair, R. E. Andersin, R. L. Tatham, and W. C. Black, Multivariate Data Analysis with Readings. New York, NY: Macmillan, 1992.

[66] P. Eckstein, Angewandte Statistik mit SPSS: Praktische Einführung für Wirt-schaftswissenschaftler. Wiesbaden: Gabler, 2004.

[67] K. Backhaus, B. Erichson, W. Plinke, and R. Weiber, Multivariate Analysemethoden: Eine anwendungsorientierte Einführung. Berlin, Heidelberg: Gabler Verlag, 2016.

[68] J. H. Ward, "Hierarchical grouping to optimize an objective function," Journal of the American Statistical Association, vol. 58, pp. 236-244, 1963.

[69] G. Punj and D. W. Stewart, "Cluster analysis in marketing research: Review and suggestions for application," Journal of Marketing Research, vol. 20, pp. 134-148, 1983.

[70] J. McQueen, "Some methods for classification and analysis of multivariate observations," in Proceedings of the Fifth Berkeley Symposium on Mathematical Statistics and Probability, 1967, pp. 281-297.

[71] M. N. Khalid, "Cluster analysis: A standard setting technique in measurement and testing," Journal of Applied Quantitative Methods, vol. 6, no. 2, pp. 46-58, 2011.

[72] B. K. Balakrishnan, M. I. Dahnil, and W. J. Yi, "The impact of social media marketing medium toward purchase intention and brand loyalty among Generation Y," Procedia-Social and Behavioral Sciences, vol. 148, pp. 177-185, 2014.

[73] N. Bayindir and E. W. Paisley, "Brand discovery examining the ways digital consumers discover new brands, products and services," in Insights Report 2019, 2019. 